\title{
WIDER
}

World Institute for Development Economics Research

\author{
Discussion Paper No. 2002/100
}

\section{Economic Aspects \\ of the Palestinian-Israeli Conflict}

\author{
The Collapse of the Oslo Accord
}

\author{
Fadle M. Naqib*
}

October 2002

\begin{abstract}
Since October 2000 Israel and the Palestinians of the West Bank and Gaza Strip have become entangled in a bloody confrontation. This paper focuses on the economic relationship between the Israeli economy and the Palestinian economy of the West Bank and Gaza Strip, and the ways in which this has contributed to the collapse of the Oslo Accord. The paper finds that Israeli policies have distorted and weakened the Palestinian economy, particularly in the areas of trade (dependence upon one major trade partner), taxation (loss of revenues to finance development spending) as well as in the labour market (controls on flows of workers) and in Palestinian access to land (including land confiscation). As a result, poverty and unemployment have risen in the West Bank and Gaza Strip. Resolution of these economic problems is therefore crucial to building a durable peace.
\end{abstract}

Keywords: conflict, Middle East, Israel, Palestine

JEL classification: O53, O10

Copyright @UNU/WIDER 2002

* University of Waterloo (Canada), email: fmnaqib@watarts.uwaterloo.ca

This study has been prepared within the UNU/WIDER project on Why Some Countries Avoid Conflict While Others Fail, which is co-directed by Tony Addison and Mansoob Murshed. 
UNU World Institute for Development Economics Research (UNU/WIDER) was established by the United Nations University as its first research and training centre and started work in Helsinki, Finland in 1985. The purpose of the Institute is to undertake applied research and policy analysis on structural changes affecting the developing and transitional economies, to provide a forum for the advocacy of policies leading to robust, equitable and environmentally sustainable growth, and to promote capacity strengthening and training in the field of economic and social policy making. Its work is carried out by staff researchers and visiting scholars in Helsinki and through networks of collaborating scholars and institutions around the world.

UNU World Institute for Development Economics Research (UNU/WIDER)

Katajanokanlaituri 6 B, 00160 Helsinki, Finland

Camera-ready typescript prepared by Liisa Roponen at UNU/WIDER

Printed at UNU/WIDER, Helsinki

The views expressed in this publication are those of the author(s). Publication does not imply endorsement by the Institute or the United Nations University, nor by the programme/project sponsors, of any of the views expressed.

ISSN 1609-5774

ISBN 92-9190-326-4 (printed publication)

ISBN 92-9190-327-2 (internet publication) 


\section{Introduction}

Since October 2000, Israel and the Palestinians of the West Bank and Gaza Strip have become entangled in a bloody confrontation that claimed thousands of casualties from both sides. After countless efforts at mediation by the international community, the crisis has shown no sign of abating. In fact its intensity has been continuously heightened by the dynamics of escalation from one side and counter-escalation from the other side. This has shattered the hopes for peaceful resolution to the Palestinian-Israeli conflict that were raised by the signing of the Oslo Accord in 1993.

The attempt of the international community to put an end to the violence and rescue the Oslo Accord proved to be a futile effort because the accord itself is flawed and cannot be resurrected. The accord, as well as the present international efforts led by US to put life into it, failed to address two central issues of the conflict: the Palestinian right to sovereignty over their land and their right to free their economy from its colonial dependency on the Israeli economy. Not recognizing the centrality of these two issues, the Oslo Accord and the present international efforts at reviving it, deal with symptoms of the conflict (violence) and ignore its cause (sovereignty).

This paper is confined to the economic aspects of the conflict. It sets out to analyse the economic relations between the Israeli economy and the Palestinian economy of the West Bank and Gaza Strip. The aim is to analyse the dynamic relation between the two that has led to the collapse of the Oslo Accord. This analysis will reveal the various anomalies in the relation, whose removal is a prerequisite for any serious and genuine effort at reviving the peace process and allowing the economic dimension to promote security for both parties. The second section outlines the historical perspective, tracing the events that took place from the signing of the Oslo Accord in 1993 to the present conflict. The third section provides the theoretical framework within which the relationship between the two economies is examined. It focuses on the interconnections between a large, advanced economy and a small, poor neighbour, as formulated by Myrdal (1957), Thirwall (1994), and Krugman (1998). It identifies the positive consequences of any linkage between the two economies, which tend to help the small economy expand, develop and grow; these are called the spread effects. It also identifies negative repercussions that tend to work in the opposite direction and thus retard the evolution of the small economy, reinforcing its underdevelopment; these are called the backwash effects. In the fourth section practices and policies of successive Israeli governments are identified as responsible for incapacitating the normal operation of the market forces in the Palestinian areas, blocking the positive spread effects and bolstering the backwash effects as the dominant force in the relation. Section five explores the changes brought about by limited self-rule (the Oslo Accord) and illustrates how these changes have failed to alter the essential dynamics of Israeli activities, and thus could not arrest the cumulative movement of the backwash effects which continue to weaken the Palestinian economy. Finally, conclusions relating to the present situation of the Palestinian economy and the prospects for future relations with the Israeli economy based upon a more equitable foundation are presented. 


\section{The Oslo Accord and limited self-rule}

On 13 September 1993, Israel and the Palestine Liberation Organization (PLO) signed a Declaration of Principles (DoP) in Washington DC, recognizing each other and resolving to implement some specified steps gradually, as well as negotiate the end of their historical conflict. As specified in the DoP, in May 1994, a Palestinian limited self-government was established over parts of the West Bank and Gaza Strip.

The new arrangement engendered high expectations of improvement for the Palestinian areas. Self-government was envisaged as setting free the West Bank and Gaza Strip from the harsh conditions of the Israeli occupation, which began with the seizing of the territories by Israel from Jordan and Egypt during the 1967 Arab-Israeli War, and creating a new environment conducive to the expansion of production and trade. Peace and stability would encourage domestic economic activities, attract foreign investment, and open the door to regional coordination and integration. In addition, the international community's commitment to underwrite part of the cost of the Palestinian reconstruction programme was seen as supplying much needed capital and foreign exchange. 1 Seven years of limited self-rule, however, have not brought about any of these expected improvements. On the contrary, the economic situation in the West Bank and Gaza has deteriorated steadily: reaching crisis proportions during the 1996-97 period, with a sharp increase in unemployment, a drastic decline in trade, an unprecedented spread of poverty, and a overall condition usually associated with economies under siege (Roy 1998: 20).

The Israeli government blames the Palestinian Authority (PA) for the deterioration of the economic situation. The failure of the PA to prevent Hamas, a militant Palestinian organization dedicated to ousting the Israeli presence from the territories, from carrying out violent acts against Israel has led the Israeli government to close its borders to the Palestinian territories, causing a drastic decline in Palestinian employment, production and trade. 2 The PA, on the other hand, while condemning the acts of Hamas, points to the Israeli government's actions as the real culprit in creating an atmosphere of conflict and strife conducive to violence. These actions include the continued building of Jewish settlements in the West Bank and Gaza, reneging on many agreements signed with the PA, and a disposition regarding self-rule as merely another form of occupation.

As is often the case, fierce polemics about responsibility and blame are arguments over symptoms rather than causes. They represent a smokescreen, disguising the failure to address deep-rooted problems that provide the fertile ground for violence. The inability of limited self-rule to deliver on its promises during the first seven years of the interim period is due primarily to the fact that it was an outcome of a flawed process; the Oslo I and II Accords, the Paris Protocol, and the Wye River Memorandum. 3 These accords

1 The US administration convened an international conference of 42 countries during October 1993, which promised 2.4 billion dollars to help the Palestinian reconstruction and development programme (1994-99).

2 The circle of violence took a very dangerous turn with the Hebron massacre in February 1994, when a Jewish extremist murdered several Muslims at prayer in the mosque. It was escalated by attacks by Hamas suicide bombers on civilians in Jerusalem and Tel Aviv, which peaked during October 1994 and again in February and March 1996.

3 The DoP is known also as Oslo I. On 29 April 1994 in Paris, the two sides signed the 'Protocol on Economic Relations between the Government of Israel and the PLO, representing the Palestinian 
simply did not deal with the crux of the problem, which is the dispute over sovereignty, and they did not change the colonial-like relationship between the Israeli and Palestinian economies. Postponing the resolution of this core problem to a later date of final status negotiations, one of the main outcomes of the Oslo process, has proved to be harmful to the peace process in general. At the political level, it has furnished the enemies of the accord, from both sides, with sufficient time to derail its implementation.

At the economic level, despite some improvements in the policy environment brought about by establishing a Palestinian national authority and dismantling some of the occupation's harmful structures, the continued Israeli confiscation of Palestinian lands and the building of new Jewish settlements, as well as expanding old ones, have created a poisonous atmosphere of strife. The relapse into the old habits of daily scuffles and clashes between the Israeli security forces and the Palestinians protesting Israeli settlements and land policies has suffocated the euphoric mood that had greeted the signing of the first peace accord. It led to deterioration in economic relations and prevented any serious movement toward reconstruction and development of the Palestinian economy. Indeed, this untenable situation precipitated the eruption of the $A l$ Aqsa Intifada on 28 September 2000. This second Palestinian uprising, 4 which passed its twenty-first month at the time of writing (June 2002), was started by Palestinian youth demonstrating against the occupation and throwing stones at Israeli soldiers. 5 Israel reacted by unleashing its superior military force, equipped with the most advanced technology, taking a terrible toll on life. Palestinian militant organizations reacted to this Israeli brutality by attacking Israeli soldiers and settlers, and by a wave of suicide bomb attacks on Israeli cities, which resulted in the death of scores of Israeli civilians. 6 This has created a vicious circle of escalation from one side and counterescalation from the other side, creating a climax at the end of March 2002 with the Israeli army reinvading most of the West Bank. This campaign, which is considered the largest Israeli military operation in the Palestinian territory since the 1967, has resulted in the total destruction of the PA's security and police apparatus in the West Bank, overwhelming damage to the Palestinian infrastructure, the ransacking and looting of most ministries and various private institutions, and the arrest of thousands of Palestinians activists and officials.7,8 In 2002, after four weeks the Israeli army

People'. This sixty-page document 'establishes the contractual agreement which will govern the economic relations between the two sides, and which will cover the West Bank and Gaza Strip during the interim-period'. On 28 September 1995, the Israeli- Palestinian Interim Agreement on the West Bank and Gaza Strip (known as Oslo II) was signed. The last agreement, the Wye River Memorandum, was signed on 23 October 1998.

4 The first Palestinian Intifada erupted at the end of 1987 and continued intermittently till the signing of the Oslo Accord in 1993

5 The clashes started when Ariel Sharon, the leader of the right-wing party, the Lukud, made a provocative visit to the Harem Al-Sharif (the Noble Sanctuary) in Jerusalem, accompanied by 1,000 Israeli police on 28 September 2000.

6 By the end of June 2002, 1,759 people had been killed on the Palestinian side, and 574 on the Israeli side.

7 The campaign is known as Operation Defensive Wall, which was waged on 29 March 2002, as a retaliatory operation to a Palestinian suicide bomb that killed 27 and injured scores of Israeli in the city of Natania two days before. 
withdrew from inside the major towns and refugee camps of the West Banks and relocated to positions surrounding them. However, this situation did not last more than a few weeks. In a response to a new wave of suicide bombers, the Israel army went back and reoccupied most of West Bank on 16 June 2002, signifying the final collapse of the Oslo Accord.

As a result of all of this, the economic situation has deteriorated massively. By the end of April, Palestinians losses had reached US\$ 3.49 billion, which is equivalent to three-quarters of the Palestinian GDP.9 According to the World Bank the unemployment rate in the Palestinian territories has passed the 50 per cent mark, and at least 50 per cent of Palestinians are living below the poverty line of US\$2 a day as of April. The United States Agency for International Development (USAID) has warned of the dangers of deteriorating health and nutrition status of women and children. 10

The ongoing situation shows no signs that an end to the violence and a return to peaceful negotiations are near. On the contrary, escalation and its negative responses have been dominating the politics of both sides and threatening to engulf the whole region in another round of Arab-Israeli wars.

It is both surprising and frustrating that the international community has failed so far to exert enough pressure on the two parties to bring about a peaceful application of the UN resolutions regarding the conflict. There is a growing concern among the Europeans, and certainly among the Arabs, that the complete support of the US government for Israel is one of the crucial factors contributing to the failure of international diplomacy to resolve the conflict. It seems that the American administration after 11 September 2001, and as part of its declared war on terrorism, has de-legitimatized the Palestinian leadership as tainted with terrorism, and sanctioned the Israeli government policies of continuing occupation, expansion of Jewish settlements, confiscation of lands and demolishing houses as legitimate practices of fighting terrorism. ${ }^{11}$ This perspective is

8 Several media and human rights organizations have accused the Israeli army of committing atrocities and war crimes during the Operation Defensive Wall, in particular during the battle that took place in Jenin refugee camp. Reacting to these claims, the UN Security Council voted to send a fact-finding mission to investigate what happened in Jenin, and the General-Secretary named a team of distinguished personalities to carry out the mission. Israel, however, refused to cooperate with the mission and subsequently the team was disbanded.

9 This is an estimate by the Palestinian Central Bureau of Statistics (PCBS). It includes US\$ 2,038 million of direct losses to economic activities, US\$ 757 million losses of Palestinian workers who lost their work in Israel, and US\$1000.6 million losses caused by damages of Palestinian assets and infrastructure (PCBS 2002).

10 It is reported that 12.5 per cent of women were either mildly or strongly anaemic while that was the case with 21.5 per cent of the children (The Chicago Tribune, 19 July 2002).

11 On 24 June 2002, President George Bush made a policy speech on the Israeli-Palestinian conflict. He did not ask Israel to lift the curfew imposed on most of the cities in the West Bank and withdraw its army from the Palestinian authority's areas, nor did he ask to put a stop to the expansion of Jewish settlements on Palestinian land. But he called on the Palestinians to change their leadership and embark on a programme of reform. The speech was treated in most European and Arab media as onesided 'vision' that will do little to bring peace to the Middle East. In the words of The Economist (29 June 2002), "even Israelis admitted that the peace plan George Bush and his divided 
most unfortunate, as it does not distinguish between terrorism and legitimate resistance activities in pursuance of self-determination and freedom from foreign occupation.

To revive the peace process, the US administration needs to take a more even-handed approach. While it is understandable that it should condemn certain activities of the Palestinians regarding targeting Israeli civilians, it should also condemn the excessive use of force by the Israeli army that has resulted in Palestinian casualties being three times larger than that of the Israelis. At the same time, the US will not be credible as an honest broker between the two parties unless it adheres to international law and declares that Israeli settlements of the occupied territories to be illegal, and incompatible with peaceful solution. A new balanced American position, and allowing for an effective role to be played by the UN, EU, and Russia, would go a long way in cementing the road toward creating a new peace process that avoids the mistakes of Oslo, especially those in economic relations.

\section{The dynamic relations between the Israeli and Palestinian economies}

In 1967 Israel occupied the West Bank and Gaza Strip and integrated their markets into its own. The Israeli economy at that time was around ten times the size of the Palestinian economy, its product diversification was much greater, and the manufacturing sector's GDP share was more than four times larger. The differences in size and structure were thus between a large, advanced, and rich economy and a small, underdeveloped, and poor economy. Both theoretical analysis and empirical studies suggest that the dynamics of such a relationship always generate two opposing forces that disproportionately affect the smaller economy and shape its development. A favourable repercussion is an increased demand for the products of the small economy, a diffusion of technology and knowledge, as well as other spread effects resulting from the geographical proximity to a large market leading to subcontracting, joint ventures, and coordination in tourism and other services. Unfavourable repercussions arise from the disappearance of many industries in the small economy, its confinement to producing low-skill goods, and the emigration of a sizeable segment of its labour force to the neighbouring economy, as well as to other countries. These effects are known in the literature as backwash effects or polarization effects, arising from the capability of efficient, large-scale industries in the advanced economy to out-compete inefficient small-scale industries in the less advanced economy, and attract its labour and capital. 12

From the perspective of the small economy, therefore, the crucial question is the balance of the dynamic impacts. To what extent would they help its own development, and to what extent would they reinforce underdevelopment? Among the factors that determine the relative strength of these two trends is the degree of integration between the two sides, which can be appreciated by considering trade. A removal of tariff and other barriers to trade between the two countries would increase the exports of the small

administration set forth this week could just as well have been written by their own prime minister, Ariel Sharon'.

12 For a good analysis of these effects, see Krugman and Obstfeld (1994), Krugman (1998), and Thirlwall (1994). 
economy to its neighbour, as trade between them takes on a pattern based on comparative advantage. This level of exports, however, will not be sustained if free trade between the two countries is accompanied by a common external tariff (as in custom union), where the tariff is substantial and is set, as it most likely would be, with the objective of protecting the advanced economy's industries. Such protection would increase the price of intermediate and capital goods imported by the small economy, and thus raise its cost of production, so compromising its comparative advantage.

Further measures of integration between the two economies, such as allowing free movement of labour and capital, would significantly reduce the export of goods from the small to the large economy, as the export of labour services would be substituted for the export of goods. In other words, free trade and free mobility of factors would gradually wipe out trade based on comparative advantage and confine it to trade based on absolute advantage, resulting in the small economy exporting low-skilled goods and importing high-skilled goods, thus 'locking in' its poverty and ensuring it remains a backward region in an otherwise advanced country. 13 Had the integration between the two countries been allowed to proceed at a slower-paced free trade between the two sides first, without a common external tariff and free mobility of factors, producers in the small economy would have been able to expand production by taking advantage of scale economies, and enhancing a comparative advantage favourable to development. In short, a slow pace of integration would improve the comparative advantage of the small economy by tapping the spread effects, whereas a hasty integration would destroy comparative advantage through the working of the polarization effects.

Immediately, after occupation in 1967, Israel imposed on the West Bank and Gaza Strip a custom union trade arrangement that increased tariffs approximately fourfold (German-Arab Chamber of Commerce 1995: 57). Naturally, this drastic change, along with the many non-tariff barriers applied by Israel, resulted in a huge trade diversion away from neighbouring Arab countries and the rest of the world toward the Israeli market, raising the cost of capital and intermediary goods to Palestinian producers that effectively wiped out their competitive edge in foreign markets. Recent studies show, for instance, that the cost of garment production in the West Bank is larger than that of Jordan by a factor of 2.17 (Makhool 1996:34). An important component in that difference is due to the fact that Palestinian producers pay double the price for their imported Turkish textiles, compared to the superior-quality East Asian materials imported by Jordanian producers. The Palestinians cannot import the Asian textiles because of the prohibitive tariff imposed by Israel to protect its own industry. Similarly, the cost of agricultural products, pharmaceuticals, and shoes in Jordan is lower than in Palestine partly because of the differences in imported input prices. Another reason for the high cost of Palestinian production in both agriculture and industry is the relatively high wage rate. It is estimated that wages of Palestinian workers are larger than those in Jordan by a factor of two to three in agriculture, a factor of two in the garment industry,

13 The advanced economy is generally more productive in the majority of sectors. The small economy will be able to export to the large economy goods that have no absolute advantage in production, provided it has smaller productivity disadvantages and its labour accepts wages lower than those prevailing in the large economy. In the long run, no industry will survive in the small economy unless it enjoys an absolute advantage over its counterpart in the large economy, and that means a predominance of low-skilled industries. 
and a factor of 2.3 in the shoe industry. 14 These high wages are the result of distortions in the labour market created by the hiring of Palestinian commuters to work by the day in Israel. A practice started with the occupation and steadily increased to account for almost one-third of the Palestinian labour force in the 1990s (UNCTAD 1998: 47). Naturally, this trade arrangement has increased the cost of Palestinian production, causing Palestinian exporters to lose their comparative advantage in traditional neighbouring markets. More importantly, economies of scale realized by the advanced Israeli manufacturers enabled them to undercut the small Palestinian firms producing for the domestic market, disrupting and replacing Palestinian artisan and small industry production.

While these adverse polarization effects were at work, various positive spread effects were also introduced by the occupation at the same time. These include the new opportunities that opened up for employment in and trade with Israel, and for some transfer of technology. The income earned by Palestinians working in Israel contributed to rapidly rising money income and, in turn, to increased demand and domestic economic activities. Palestinian agriculture benefited from a transfer of technology from the more advanced Israeli agriculture and this contributed to increased exports of some agriculture products to Israel. The cumulative impact of this expansion in economic activities helped increase income, saving, and investment, especially investment in residential construction.

\section{The role of Israeli measures in creating an adverse path dependence}

Had the economic relations between Israel and the Palestinian territory been confined entirely to the dynamic forces described above, the positive spread effects would probably have dominated the adverse polarization effects by the end of the second decade of the occupation. The higher cost of living in Israel and the external diseconomies produced by congestion would have outweighed the benefits of greater efficiency and given way to

Table 1

Comparison of GDP per capita in Israel and the Palestinian Territories

\begin{tabular}{lccc}
\hline Year (a & Israel (1) & West Bank \& Gaza (2) & Ratio (3) $=(2)-(1)$ \\
\hline $1968-69$ & 6,043 & 601 & 0.09 \\
$1975-76$ & 8,163 & 1,026 & 0.13 \\
$1980-81$ & 8,613 & 1,252 & 0.15 \\
$1985-86$ & 9,051 & 1,264 & 0.14 \\
$1990-91$ & 0,912 & 1,320 & 0.13 \\
$1995-96$ (b & 16,694 & 1,626 & 0.10 \\
$1997-98$ & 16,492 & 1,523 & 0.09 \\
$1999-2000$ & 17,300 & 1,504 & 0.08 \\
\hline
\end{tabular}

Notes: (a Average of two years is taken to neutralize variations in the Palestinian GDP caused by the cyclicality of the olive crops.

(b GDP per capita for 1995-2000 are in current prices.

Source: $\quad$ Calculated by using Statistical Abstract of Israel $(1998,2000)$ : World Bank (1993: 135, Table 1) and MAS (2000).

14 For analysis of the cost of agricultural products, see Awartani (1994), and for similar analysis related to garments, pharmaceuticals, and shoes, see Makhool (1996). 
increased investments in the Palestinian economy. Increased economic activities in the Palestinian territories would then have gradually corrected the distortion in the labour market by reducing the number of Palestinians seeking daily work in Israel. The spread effects would have certainly asserted themselves and generated a process whereby Palestinian income was created endogenously in the internal productive sectors, rather than outside. Instead, we see that the relation between the two economies has followed quite a different path.

As is shown in Table 1, the Palestinian economy benefited significantly from its relation with Israel in just the first decade, and then that relationship became harmful. In the first decade the Palestinian GDP per capita grew from nine per cent of that of Israel to fifteen per cent, but then the ratio declined continuously, and at the start of the limited self-rule was almost at the level of a quarter of century before. Thus, in the first decade of occupation the relation between the two economies went through a process of convergence; the poor economy grew at a rate faster than the rich economy. Afterward, the process was reversed and became one of divergence, with the rich economy growing at a faster rate. The reason for this reversal is that the economic relationship between the two economies was not confined to the working of the polarization and spread effects operating through the market. The policies practised by Israel since the start of occupation, which increased in intensity and aggressiveness in the mid-1970s, have circumvented the forces in the market, bolstering the effects of polarization and diminishing the spread effects.

These policies and practices include the following measures.

\subsection{Restriction on the use of natural resources}

Since the start of the occupation, the Palestinians in the West Bank and Gaza Strip have increasingly lost control over their land and their supply of water. The Israeli authorities used many different and complex measures and policies, all of which were designed to place under Israeli control the largest possible area of land, and the maximum amount of water. It is widely believed that by the time of the establishment of the Palestinian limited self-rule, Israel had confiscated 68 per cent of the total land of the West Bank, and 40 per cent of that of Gaza Strip (UNCTAD 1996: 98). On the other hand, estimates indicate that Palestinians in the West Bank use only about 15 to 20 per cent of the annually available water originating in the area. The rest is used by Israeli settlers and within Israel (World Bank 1993: vol IV: 54). New Jewish settlements were built on part of the land taken from Palestinian use and control. The rest of the confiscated land was turned into closed military areas. By the end of 1991, the number of these settlements had reached at least 156 in the West Bank and 18 in Gaza Strip, with a population of 250,000.15 These Israeli policies toward land, water, and settlements have created an atmosphere of conflict, strife, and uncertainty, with a profoundly negative effect on all economic activities. The direct adverse effect was felt most strongly in agriculture, where the area of irrigated land has declined by 6 per cent, and where prices of land and water increased to a very high level (World Bank 1993, vol IV: 20). This distortion of prices, combined with the refusal of the Israeli authorities to allow for the normal

15 By 1997 the population had reached 346,500. See the Foundation for Middle East Peace, available at: www.fmep.org. 
expansion of municipal boundaries, has also resulted in high building costs for new industrial plants, and thus acted as a strong barrier to industrial expansion.

\subsection{Restrictions on the economic activities of the productive sectors}

In addition to the removal of land and water from Palestinian control, the Israeli authorities have followed a general practice aimed at changing the structure and performance of the Palestinian economy. All economic activities were placed under the scrutiny of the Israeli military administration in the territories, and every economic undertaking required its approval. Plans by Palestinian businessmen to start new ventures, or to expand old ones, were often frustrated by delays in granting the appropriate permit, or in outright denial. Permits were required for all activities related to the acquisition of land, the construction of buildings, the transformation of goods, and export and import activities.

The taxation of Palestinian business activity was equally detrimental. Palestinian firms have had to pay value-added tax (VAT) on all their imports of raw materials through Israel. The long delay in receiving the refunds of this tax caused these firms severe problems of cash flow and shortage of capital. This has resulted in an annual loss estimated to be 8 to 12 per cent of the value of their finished products (World Bank 1993, vol III: 16).

While these measures distorted incentives, and increased the risk to business activities, investment was further discouraged by the underdevelopment of effective financial intermediation in the Palestinian economy. This reflected the fact that all Arab banks were closed at the beginning of the occupation and only reopened on a very small scale in the mid-1980s.

Another important restriction is related to technological change and modernization. The Israeli authority did not permit Palestinian firms to import machines and tools incorporating the latest technology. Instead, they were compelled to buy second-hand machines from Israel.

It should also be noted that the custom union arrangement Israel imposed on the territories, was, in effect, an asymmetric trade scheme. This allowed Israel's own heavily subsidized products free entry into Palestinian markets but prevented the entry of Palestinian products into the Israeli market, except on a selective and limited basis. This asymmetric trade relation, combined with complex administrative procedures aimed at discouraging Palestinian exports to the rest of the world, has made Palestinian trade completely dependent on Israel. The fact that 90 per cent of all Palestinian imports come from Israel presents one side of this forced dependency. The other side is shown in the fact that Palestinians pay for these imports partly by exporting labour services to Israel, and partly by exporting goods manufactured under subcontracting arrangements with Israeli firms.

\subsection{Resource transfer to Israel, and the neglect of the public sector}

The forced integration of the Palestinian economy into that of Israel was associated with a transfer of resources from the former to the latter. Three channels were involved. First, Palestinians paid VAT and custom duties on products imported from Israel. It is 
estimated that half of the taxes paid by Palestinians in the Occupied Territories accrued to the Israeli treasury in this way (Fischer et al. 1994: 120). The second source is the income tax and social security contributions paid by Palestinians working in Israel. The third was the seigniorage revenue Israel received because its currency was made legal tender in the Occupied Territories. The total of these resource transfers is large, and according to some estimates has reached, in any given year, from 15 per cent to a quarter of the Palestinian GNP.16 Given that Israel was not prepared to undertake public expenditures in the Occupied Territories beyond the tax revenues actually raised there (as opposed to those paid by Palestinian consumers and workers but collected in Israel), all public infrastructure in the West Bank and Gaza Strip is in a very poor state, and the level and quality of public services and utilities are far below that of neighbouring countries. 17 The poor condition of the basic infrastructure and public services causes market fragmentation, and this inhibits specialization and the realization of economies of scale that are essential for a small economy to be competitive.

The cumulative impact of the foregoing restrictions on resource use, business activities, and domestic and international trade has substantially weakened the traditional productive sectors of the Palestinian economy. This has caused a general reallocation of factors of production, combined with the reorientation of the trade flows, to the benefit of Israel. As a consequence, a major structural transformation of the Palestinian economy has taken place. It has become an economy characterized by two growing disequilibria: a resource gap and labour market imbalance, and a great and unhealthy dependence on external sources of income. It also features a sectoral disarticulation and an infrastructure gap.

\subsection{The resource gap}

The Palestinian economy suffers from a chronic incapacity to generate more than two-thirds of its national income. Usually, the yearly total domestic absorption (domestic consumption and investment and government expenditures) is more than one and a half times the economy's total production (GDP). Imports fill this gap, and assume a very important role in the economy. In the years preceding the establishment of limited self-rule, the import surplus (imports over exports), measured as a percentage of GDP, had reached 59 per cent and had never been less than 43 per cent (see Table 2). The financing of these huge imports was generated mainly from the income of Palestinians working in Israel, and the remittances of those working in the Persian Gulf states. These factor incomes account for the wide disparity between gross national product (GNP) and GDP, and are also shown in Table 2.

Another manifestation of the resource gap and the central role played by factor incomes is the investment-saving imbalance. Domestic savings in every year of the occupation were negative. Thanks to factor income, however, national saving was positive, and generated part of the funds needed for investment; the rest has been acquired from foreign savings.

16 See Hamed and Shaban (1993) and Luski and Weinblatt (1994).

17 This Israeli behaviour is quite consistent with past British and French colonial behaviour in the Middle East. One of their major underlying economic principles was that 'colonies should pay for themselves without recourse to special financial assistance from the metropolis'. See Owen and Pamuk (1999: 52). 
Table 2

The resource gap (\%)

\begin{tabular}{lrrrrrrrr}
\hline & 1968 & 1975 & 1980 & 1985 & 1990 & 1995 & 1998 & 2000 \\
\hline Import surplus (a & 34 & 59 & 45 & 56 & 39 & 37 & 42 & 65 \\
Investment surplus (b & 43 & 24 & 16 & 15 & 5 & 28 & 28 & 36 \\
GDP/GNP & 107 & 78 & 80 & 77 & 75 & 93 & 86 & 87 \\
\hline
\end{tabular}

Notes: (a Defined as (imports - exports) / GDP;

(b Defined as (investment - saving) / GNP;

Source: Calculated by using World Bank (1993: Table 1), and a memo issued by the Palestinian National Authority (Ministry of Finance) October 1998, and UNCTAD (2001).

\subsection{The labour market imbalance}

The mirror image of the resource gap is the imbalance in the labour market between the growing supply of labour, reflecting both a high natural rate of growth and the age structure of the population, and the limited capacity for employment due to the hostile economic environment of the occupation. Between 1972 and 1987 the labour force increased by around 50 per cent, while domestic employment increased by 27 per cent in the West Bank, and 18 per cent in Gaza Strip. The difference was mainly absorbed by the Israeli market, in which employment of Palestinians from the West Bank increased by 80 per cent, and from Gaza strip by 163 per cent, in the same period. Table 3 shows the main features of the labour market.

Table 3

The labour force imbalance (thousands)

\begin{tabular}{lrrrrrrrr}
\hline & 1968 & 1975 & 1980 & 1985 & 1990 & 1995 & 1997 & 2000 \\
\hline Labour force & 146.6 & 206.6 & 218.5 & 251.5 & 307.8 & 497.2 & 572.7 & 787.0 \\
Number of employed & 128.0 & 264.7 & 215.7 & 242.1 & 297.0 & 402.9 & 444.9 & 592.0 \\
Percentage of employed in Israel (\%) & 0.0 & 32.4 & 34.8 & 36.8 & 36.4 & 16.1 & 16.1 & 16.9 \\
Unemployment rate (\%) & 13.1 & 0.9 & 1.3 & 3.6 & 3.7 & 18.2 & 22.1 & 37.0 \\
\hline
\end{tabular}

Source: Farsakh (1998: Tables 2 and 5) and UNCTAD (2001).

\subsection{The sectoral distortion}

While the resource gap and the labour market imbalance portray weaknesses of the Palestinian economy at the macro level, the sectoral distortion pertains to the underlying causes of this weakness at a micro level. Table 4 presents the Palestinian sectoral shares in GDP, along with those of neighbouring countries. The harmful structural transformation noted above is revealed by the fact that the share of agriculture in Palestine is the highest, and its share of industry is the lowest. It is striking that the Palestinian agricultural share is more than four times that of Jordan, while its share of industry is little more than half that of Jordan. 
Table 4

The sectoral disarticulation: Sectoral share in GDP (\%)

\begin{tabular}{lcccc}
\hline & Palestine & Jordan & Egypt & Israel \\
\hline Agriculture & 25 & 6 & 18 & 2 \\
Industry & 10 & 17 & 30 & 22 \\
Construction & 14 & 7 & na & 10 \\
Services & 48 & 37 & 52 & 65 \\
\hline
\end{tabular}

Source: The figures for Palestine are calculated as an average of two years to smooth the olive cycle. They are taken from estimations of the UNCTAD Secretariat for the years 1992-93. The rest of the figures are calculated for 1991 at current prices (World Bank 1994: Table 1.2).

\subsection{The infrastructural gap}

Fiscal compression and under-investment as well as neglect in the public sector have made the Palestinian economy seriously deficient in most infrastructures and public services. Table 5 shows that the Palestinian economy is lagging behind in all infrastructure provision compared to its neighbours. Transportation and sanitation are in dire straits. Almost all the major roads in the West Bank and Gaza Strip were constructed before 1967, and have received minimal maintenance during the years of occupation. Sanitation is in a health-threatening condition, as only 25 per cent of households in the West Bank and Gaza Strip are connected to sewerage networks. Garbage collection is deficient and poses a major health hazard. One feature of Table 5 is especially noteworthy; at the regional level, Israel is ranked first, and the Palestinian territories last in infrastructural provision.

\begin{tabular}{|c|c|c|c|c|c|c|c|}
\hline Country & 苏 & $\begin{array}{l}\text { 정 } \\
\text { 힘 }\end{array}$ & 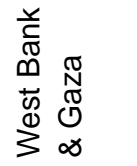 & $\begin{array}{l}\text { 동 } \\
\frac{1}{\widetilde{J}} \\
\text { O }\end{array}$ & 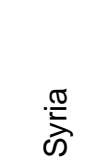 & $\begin{array}{l}\bar{\Phi} \\
\frac{\pi}{\omega} \\
\underline{\omega}\end{array}$ & $\begin{array}{l}\mathbb{0} \\
\mathcal{O} \\
\sum\end{array}$ \\
\hline Population & 55.0 & 3.9 & 2.4 & 4.0 & 13.0 & 5.1 & $1,152.6$ \\
\hline Per capita income, US\$ & 650 & 1,120 & 1,450 & 2,500 & 2,800 & 13,500 & 1,620 \\
\hline Electric supply kw per 100 people & 21.0 & 25.0 & 13.0 & 32.0 & 30.0 & 82.0 & 21.5 \\
\hline Electric power system loss, \% & 14.0 & 19.0 & 30.0 & na & na & 4.0 & 12.4 \\
\hline Households with sanitation, \% & 50 & 100 & 25 & na & 63 & 100 & - \\
\hline No. of phones per 100 people & 4.3 & 7.0 & 3.1 & 9.3 & 4.1 & 37.1 & 7.9 \\
\hline Metres of paved road per 100 people & 39 & 170 & 80 & na & 180 & 266 & - \\
\hline
\end{tabular}

Note: (a Lower middle income countries.

Source: $\quad$ Diwan and Shaban (1999).

\section{The economics of limited self-rule during the interim period}

The gradual establishment of Palestinian limited self-rule in parts of the West Bank and Gaza Strip was the result of the implementation of several agreements between Israel and the PLO. As a consequence, there was a transfer of power over some economic 
affairs from the Israeli Civil Administration (CA) to the Palestinian Authority. This included the removal of direct restrictions on business activities: Palestinian firms could now function without the crippling effects of permits and licenses previously required by the CA. Notwithstanding the importance of this, however, it should be mentioned that some of the indirect restrictions remain. These restrictions include the treatment of indirect taxes, and the tariffs on consumer durables from neighbouring Arab countries.

The asymmetric custom union regime that characterized the economic relationship between Israel and the Occupied Territories has changed in two directions under the limited self-rule. First, many elements in the asymmetry have been removed. In principle, Palestinian goods should receive the same treatment in Israel that Israeli goods receive in Palestine. Second, some elements of a free trade area regime have been introduced. The PA will have the freedom to choose its own tariff rates on three lists of goods, including goods that can be imported from or through Jordan and Egypt.

While the monetary arrangements during the transitional period are an improvement over those of the occupation, they are certainly not optimal. Arab banks reopened and new ones were established, and behaviour is monitored by the Palestinian Monetary Authority (PMA), which has some of the functions of a central bank but not the right to issue national currency. The Israeli currency (the shekel) and the Jordanian currency (the dinar) are used as legal tender. Thus the monetary arrangements combine some of the worst aspects of two polar-type exchange rate regimes. The absence of a national currency renders monetary policy ineffective, as in a fixed exchange rate regime. On the other hand, the existence of a two-currency standard has the potential for increasing those costs associated with fluctuations in exchange rates typical of a flexible exchange rate regime. In addition, a dual currency tends to reduce the ability of commercial banks to perform their function of transforming debt maturities, because of the problem of currency mismatching inherent in portfolios. This discourages them from extending long-term loans, which are essential for investment and growth.

Under the limited self-rule, some of the resource transfers to Israel have been eliminated. Seventy five per cent of the income tax collected from Palestinians working in Israel, and 100 per cent of the income tax collected from those working in Jewish settlements, will be reimbursed to the PA. Israel is also required to transfer to the PA all VAT on goods purchased in Israel by Palestinian firms. However, the resource transfer from the Palestinian economy to the Israeli economy has not been eliminated. Palestinian imports from the rest of the world, which must pass through Israel, still generate custom duties received by Israel and not transferred to the Palestinian Authority. This happens because Palestinian wholesalers and firms use Israeli traders to import from the rest of the world. A common practice of these traders is to include the Palestinian imports as part of imports destined to Israel (not the West Bank and Gaza Strip). Accordingly, customs paid by Palestinians on these imports accrue to Israel and are not transferred to the PA, as is the case of Palestinian imports from Israel destined to the West Bank and Gaza Strip. Obviously, there is no precise way of measuring the exact size of this forgone revenue, but recent studies have estimated it to be around one-third of total tax revenue and around 3 per cent of the Palestinian GDP (Naqib 1996). It should be noted, too, that Israel still collects seigniorage revenue since its currency is still legal tender in the Palestinian areas.

The most important feature of the limited self-rule is related to sovereignty and natural resources. In the Declaration of Principles (DoP), it was agreed that there would be no 
change in sovereignty over land, water, and settlements during the transitional period. These issues are left to be negotiated as part of the final settlement. Consequently, the restrictions imposed on the Palestinian use of land and water remain completely intact. The substantial restriction on the use of irrigation water in the West Bank, and the diversion of water from aquifers for use in Israel and its settlements, will continue to harm Palestinian agriculture, and prevent any serious move to expand and diversify crops. As of June 1997,

Israel directly controlled 40 per cent of the land of Gaza Strip and 74 per cent of the West Bank, the latter being known as Area C. In Area C, Israel has full authority over zoning, building, and land registration. In those West Bank lands (approximately 23 per cent) under both Palestinian and Israeli authority (Area B), the Israeli government maintains complete control over land registration procedures. It is only in Area A (approximately 3 per cent) of the West Bank that Palestinians exercise full control over land disposition (Roy 1998: 20). 18

It should be noted that the Israeli authorities retain full control over all borders, which implies control over the movement of labour and goods between the Palestinian territories and the outside world. Furthermore, the conditions under which the limited self-rule has been implemented have caused geographic segmentation with harmful economic effects. According to a World Bank report, the new situation 'split up the West Bank and Gaza into a number of largely separate economic units with little economic interrelationship among them, breaking up an already small domestic market into even smaller ones' (Roy 1996: 61)

Furthermore, the awkward arrangements of the limited-self rule have created a multidimensional uncertainty that is discouraging to both domestic and foreign investment. A prospective investor can obtain a license for starting business from the PA, but bringing capital, goods, and people for that investment from outside needs the approval of the Israeli authorities. The investor has to operate without any knowledge of the future trade and monetary arrangements. How easy will it be to export to Arab countries, the European Union (EU), or the United States? Will there be a Palestinian currency and foreign exchange controls?

Yet, none of these aspects of Israeli control, profound as they are, is the most crippling aspect of the limited self-rule. The interim period received its severest blow with the continued building of new Jewish settlements and the expansion of existing ones. 19 The growth of settlement activities since the signing of the DoP in 1993 is an unambiguous indication that the peace process, as exemplified by the limited self-rule, did not address the root of the problem; the continuing Israeli infringement of Palestinian sovereignty. In just two years after the signing of the DoP, the following Israeli activities took place (see PHRIC 1995):

18 This situation remains the same at the time of writing (June 2002).

19 The Palestinian side maintains that confiscating land and building Jewish settlements violate the spirit, if not the letter, of the Oslo Accord since it alters facts on the ground, thus prejudicing the negotiation of final settlement. 
i) Confiscation of 55,000 dunums 20 of Palestinian land (see Table 6);

ii) An area of 17,860 dunums bulldozed by settlers without being officially confiscated;

iii) Direct expansion of existing settlements by 8,993 dunums;

iv) Uprooting of 28,752 trees;

v) Chemical destruction (poisoning) of thousands of trees in the West Bank by settlers; and

vi) Use of 11,433 dunums for road construction to link settlements by bypassing Arab population centres.

All of these activities have increased in scope and intensity in the last five years, especially in Palestinian lands surrounding the city of Jerusalem. Indeed, immediately after signing the Wye Accord in October 1998, then-Foreign Minister Ariel Sharon counselled the settlers to make haste by 'grabbing hilltops' before land was turned over to the Palestinians. Israeli peace groups report that 16 new settlements were set up in the five months after the Wye Accord was signed at the White House.21 The Labour government that came afterward followed the same policy. During its tenure (June 1996-January 2001), the number of settlers increased by 22,419 (FMEP, March-April 2001). ${ }^{22}$ In the first nine months of the new Likud government under the Sharon leadership which was elected in February 2001, 25 new settlements sites were established in the West Bank, all between 200-2000 metres away from an existing settlement. The last FMEP report (June 2002) indicates that during the seven years of Palestinian limited self-rule the number of Jewish settlers has doubled.

Table 6

Israeli confiscation of Palestinian land (1990-97)

\begin{tabular}{lc}
\hline Year & $\begin{array}{c}\text { Confiscated land (dunum) } \\
(1 \text { dunum }=1 / 4 \text { acre })\end{array}$ \\
\hline 1990 & 227,335 \\
1991 & 80,594 \\
1992 & 14,669 \\
1993 & 49,466 \\
1994 & 5,119 \\
1995 & 24,867 \\
1996 & 6,000 \\
1997 & 24,938 \\
\hline
\end{tabular}

Source: For 1990-95, Palestinian Human Rights Center (PHRIC); for 1996, approximate numbers based on data provided by PHRIC; for 1997, Annual Report of the Palestinian Society for the protection of Human Rights and the Environment: Jerusalem.

20 One dunum equals to $1 / 4$ acre.

21 See the New York Times, 3 March 1999.

22 The Foundation for Middle East Peace (FMEP) issues periodical reports monitoring the Israeli settlement activities in the West Bank and Gaza Strip. 
It should come as no surprise, therefore, that the peace process did not eliminate the basis of conflict, strife, and violence. Nor is it surprising that after seven years of limited self-rule, the economic condition in the Palestinian areas is as bleak as it was under the occupation; the general well-being of the Palestinian people in the West Bank and Gaza Strip has undoubtedly deteriorated since the establishment of the limited self-rule. According to a survey conducted by the Palestinian Central Bureau of Statistics (PCBS), real per capita average expenditure in the 1995-96 survey period was about 15 per cent below its average for the years 1992-93. This deterioration in the standard of living is also manifested by the growing gap between Israeli and Palestinian per capita income. Table 1 shows that after 30 years of imposed integration between the two economies, the gap between them has expanded, signifying a dominance of the polarization effects over the spread effects. This adverse trend is also demonstrated in the performance of the Palestinian economy at the macro level, as exemplified in the continuance of the resource gap and the labour market imbalance (see Tables 2 and 3).

The steady deterioration of the Palestinian economic situation, the building of new Jewish settlements and the expansion of the old ones, together with the failure of the American sponsored conference at Camp David to reach agreement, 23 combined to heighten the Palestinian sense of frustration, anger, and helplessness. On 28 September 2000, an Israeli provocation created the spark that inflamed the Palestinian popular uprising (Al Aqsa Intifada). 24

Since the beginning of the Intifada, Israel has imposed a total closure on the Palestinian territories that caused serious dislocation of the Palestinian economy with huge losses of income. Closures comprise two types. During border closure, Palestinians are not allowed to enter Israel (including East Jerusalem) or travel to Jordan and Egypt, effectively isolating them from the rest of the world. During internal closure, Palestinians are not allowed to move among urban centres within the West Bank or to and from the surrounding villages. As a result of imposing these two kinds of closure for long periods since October 2000, the Palestinian territories have turned into small isolated islands surrounded by the Israeli army, and this fragmentation has hampered the movements of goods and factors of production. The Palestinian economy's resources have been damaged, with losses according to UN estimates being between US\$ 1.8-2.5 billion in the first eleven months (UNCTAD 2001: 6). These include declining incomes from Israel (accounting for around 20 per cent of the total losses) as well as declines in most domestic sectors. In addition, indirect losses involving destruction of infrastructure are estimated at well over US\$ 200 million for the first six months of the Intifada. Unemployment grew rapidly, sharply reaching 30-40 per cent in

23 The DoP stipulated an interim period (1994-99) during which Israel was to withdraw from specified areas in the West Bank and Gaza, transfer authority to the Palestinian Authority, and conduct with the PLO negotiations to reach a final peace settlement over issues of refugees, Jerusalem, borders, Jewish settlements, and security. However, five years passed without completion of the Israeli withdrawals, and without starting negotiations over permanent settlement. Alarmed by this failure, President Clinton brought the two sides to Camp David (July 2000) with the intention of bypassing the gradual steps as specified by the DoP, and move directly to a final agreement. But the conference collapsed without reaching any agreement.

24 Ariel Sharon, the leader of the right-wing Likud party, made a provocative visit to the cite of Al-Aqsa mosque known as Harem Al-Sharif, or Noble Sanctuary, on 28 September 2000. The visit was intended to reaffirm the Israeli claim that the cite should be forever under Israeli sovereignty as it is the cite of Temple Mount. 
the West Bank and well over 50 per cent in the Gaza Strip. The spread of poverty has reached an alarming level. It is estimated that in August 2001, 60.8 per cent of households, or 2.03 million individuals, were living below the poverty line (US\$ 2.10 per person per day). In the Gaza Strip the situation was more acute with 81.5 per cent of households reporting an income below the poverty line compared to 50.3 per cent of households in the West Bank. 25

The economic situation took a drastic turn for the worse in March-April 2002, after the Israeli army reoccupied most of the West Bank and imposed total curfew on the inhabitants of major cities.

\section{Conclusion}

One major theme has emerged from the analysis of this paper concerning the Israeli policies toward the Palestinian economy in the West Bank and Gaza Strip. During the occupation period (1967-94), those policies were responsible for weakening the productive sectors of the economy through the creation of distortion and disequilibria, and engendering crippling dependency on the Israeli economy. Obviously, a relation between two neighbouring countries in which measures taken by one can cause the other to lose overnight the income of one-third of the labour force, and interrupt quite a substantial portion of its imports and exports, is simply untenable. The disproportionality-in what might be called the cost of dissociation-renders the Palestinian-Israeli relationship unstable. It was also demonstrated that, despite some progress in institution building, regulatory and economic policy formation made during seven years of limited self-rule brought about by the Israeli-Palestinian accords, the harsh occupation environment did not actually change in any significant manner. In fact, increased uncertainty and political strife have aggravated the economic situation in the last three years, and resulted in sharp declines in Palestinian households' income, massive unemployment and increased poverty.

The failure of the limited self-rule points to a fundamental contradiction of the peace process which started with the signing of the DoP in 1993. On the one hand, the ultimate goal was to achieve a historical compromise between the two peoples through a two-state solution to the conflict; one Jewish and one Palestinian. On the other hand, the gradual step by step trajectory allowed Israel to continue its policies of land confiscation, the building of new Jewish settlements, and the attainment of complete control over borders, all of which undermined the emergence of viable Palestinian state.

The experience of the last seven years has shown that the Oslo Accord is flawed and does not have the potential for achieving a peaceful settlement. A new accord that recognizes the fundamental Palestinian right of sovereignty over their land is needed so that the two-state solution can become a viable solution to the conflict.

A new environment free of conflict over sovereignty, and a clear and well-defined authority over economic activities can take the Palestinian economy a long way toward a higher path of development and growth. Such a new and enabling environment would

25 These figures are taken from a survey conducted by the Palestine Central Bureau of Statistics (PCBS). See The Jerusalem Times, 5 October 2001. 
cement a new economic relation between the two economies that could exploit possibilities of complementarity and rationalization, and acknowledge the need of the Palestinian economy to use measures to safeguard itself against dependence upon one major trade partner.

\section{Bibliography}

Arnon, A. et al. (1997). The Palestinian Economy: Between Imposed Integration and Voluntary Separation. New York: Brill.

Awartani, H. (1994). Palestinian-Jordanian Agricultural Relations. Nablus: Center for Palestinian Research and Studies.

Diwan, I., and R. Shaban (eds) (1999). Development Under Adversity: The Palestinian Economy in Transition. Ramallah: Palestine Economic Policy Research Institute (MAS) and the World Bank.

Farsakh, L. (1998). 'Palestinian Employment in Israel 1967-1997: A Review'. Ramallah: Palestine Economic Research Institute (MAS).

Fischer, S. et al. (1994). Securing Peace in the Middle East. Cambridge, MA: The MIT Press.

Foundation for Middle East Peace (FMEP)(2002). Various documents from MarchApril. Available at: www.fmep.org .

German-Arab Chamber of Commerce (1995). 'Trade for Peace in the New Middle East'. Cairo: Commission for the European Communities.

Gorden, W. M., and A. P. Neary (1982). 'Booming Sector and De-industrialization in a Small Open Economy’. Economic Journal, 92 (December): 825-48.

Hamed, O., and R. Shaban (1993). 'One Sided Customs and Monetary Union: The Case of the West Bank and Gaza Strip Under Israeli Occupation', in S. Fischer, D. Rodrik and E. Tuma (eds), The Economics of Middle East Peace. Cambridge: The MIT Press, 117-48.

Krugman, P. R. (1998). Development, Geography, and Economic Theory. Cambridge, MA: The MIT Press.

Krugman, P. R., and M. Obstfeld (1994). International Economics: Theory and Policy. New York: Harper Collins Collage Publishers.

Lonergan, S., and D. Brooks (1994). Watershed: The Role of Fresh Water in the IsraeliPalestinian Conflict. Ottawa: International Development Centre.

Luski, I., and J Weinblat (1994). 'The West Bank and Gaza Strip: A Macroeconomic Profile and Simulation Model'. Tel Aviv: The Philip Monaster Center for Economic Research.

Makhool, B. (1996). 'Competitiveness of Palestinian Industry vs. Jordanian Industry'. Ramallah: Palestinian Economic Policy Research Institute (MAS).

Mansour, A., and B. Destreman (1997). 'Palestine and Israel: Subcontracting in the Garment Industry'. Ramallah, Palestine Economic Research Institute (MAS). 
Myrdal, G. (1957). Economic Theory and Underdeveloped Regions. London: Duckworth.

Naqib, F. M. (1996). 'A Preliminary Evaluation of the Tax System in the West Bank and Gaza Strip'. Ramallah: Palestinian Economic Policy Research Institute (MAS).

Owen, R., and S. Pamuk (1999). A History of the Middle East Economies in the Twentieth Century. Harvard: Harvard University Press.

Palestine Human Rights Information Center (PHRIC) (1995). Various documents. Jerusalem: PHRIC.

Palestinian Economic Policy Research Institute (MAS) (2000). Economic Monitor, 6: April.

Palestinian National Authority (1998). Memo by the Ministry of Finance, October.

Palestinian Society for the Protection of Human Rights and the Environment (various years). Annual Report. Jerusalem:

Roy, S. (1996). 'US Economic Aid to the West Bank and Gaza Strip'. Middle East Policy, October: 61.

Roy, S. (1998). 'The Palestinian Economy after Oslo'. Current History, 97 (615): $19-25$.

Thirwall, A. P. (1994). Growth and Development, $5^{\text {th }}$ edition. London: Macmillan.

UNCTAD (1989). 'Palestinian External Trade Under Israeli Occupation'. Document UNCTAD/RDP/SEU/1. Geneva: UNCTAD.

UNCTAD (1993). 'Development in the Economy of the Occupied Palestinian Territory'. Document UNCTAD/TD/B/40(1)): 14.

UNCTAD (1996). 'Prospects for Sustained Development of the Palestinian Economy: Strategies and Policies for Reconstruction and Development'. Document UNCTAD/ECDC/SEU/12,21, August.

UNCTAD (1998). 'The Palestinian Economy and Prospects for Regional Cooperation'. Document UNCTAD/GDS/SEU/2,30, June. Geneva: UNCTAD.

UNCTAD (2001). The Palestinian Economy: Achievements of the Interim Period and Tasks for the Future. Geneva: UNCTAD.

UNIDO (1984). 'Survey of the Manufacturing Industry in the West Bank and Gaza Strip'. Vienna: UNIDO.

United Nations (2001). 'The Impact on the Palestinian Economy of Confrontations, Mobility Restrictions and Border Closures, 1 October-31 January 2001'. Gaza: Office of the United Nations Special Coordinator, 25 February.

World Bank (1993). Developing the Occupied Territories-An Investment in Peace, vol I-VI. Washington, DC: World Bank.

World Bank (1994). Peace and the Jordanian Economy. Washington, DC: World Bank, Table 1.2. 